\title{
El-Fayah
}

JURNAL BIOLOGI

Journal Homepage: http://ejournal.uin-malang.ac.id/index.php/bio/index

e-ISSN: 2460-7207, p-ISSN: 2086-0064

Original research article

\section{Ethnobotanical And Bioeconomy Study Of Kedung Pedut Vegetation By Javanese Community In Kulon Progo Yogyakarta}

\section{Nur Ahmad Rudin ${ }^{*}$, Rini Rahmawati', Mohammad Bayu Hidayat, Muhamad Ujang Sawajir², Bondan Agung Pramono'}

${ }^{1}$ Department of Tropical Biology, Faculty of Biology Universitas Gadjah Mada

${ }^{2}$ Department of Forest Management, Faculty of Forestry Institut Pertanian INTAN Yogyakarta

"Corresponding author

Email: nur.ahmad.rudin@mail.ugm.ac.id

DOI: 10.18860/elha.v8i2.12465

\section{Article Info}

Article history:

Received 26 February 2021

Received in revised form

01 March 2021

Accepted 15 March 2021

Key Word:

Bioeconomy

Ethnobotany

Kedung Pedut

Kulon Progo

Vegetation

\begin{abstract}
Kedung Pedut is a natural waterfall located in Menoreh Highland, Kulon Progo, Special Region of Yogyakarta, Indonesia at altitude of 529 masl. Kedung Pedut has special natural vegetation characteristics, but since 2015 tourism developments was changing the composition of vegetation in this area. This makes the ethnobotany and biobased economy study are important. Therefore, this study aims to determine the abundance and utilization of vegetation in Kedung Pedut area by Javanese community in Kulon Progo and potential utilization of various vegetation in the future. The study was carried out by grid lines method and interview. Location of vegetation sampling was along the banks of river. Identification of vegetation was carried out on tree growthform. Data analysis was done by literature studies. The results of study identified 25 species of standing vegetation in Kedung Pedut. Tree vegetation with the greatest abundance are Swietenia mahagoni (4048.05 ind/ha), Paraserianthes falcataria (1700.18 ind/ha), Cocos nucifera (1484.29 ind/ha), Bambusa blumeana (782.62 ind/ha), and Tectona grandis (701.66 ind/ha). Potential utilization of vegetation in Kedung Pedut area by Javanese community in Kulon Progo based on the development of technology and science are for medicines, agroforestry, food and beverage industry, natural dyes, furniture industry, germplasm conservation, and conservation of environment.
\end{abstract}

\section{INTRODUCTION}

Kedung Pedut is a tourist destination of natural waterfall in Menoreh Highlands, Kulon
Progo Regency, Special Region of Yogyakarta. The area is located at altitude of 529 masl. Kedung Pedut has complex and natural 
ecosystem structure because still far from urban crowds and less human intervention. This causes less damage to vegetation and disturbances to living things in environment so that the balance of ecosystem is very well maintained. The vegetation composition in Kedung Pedut area is quite complex to support creation of heterogeneous ecosystem. The vegetation composition is very diverse, from seedlings, shrubs, trees and herbaceous plants. This area offers an attractive panorama accompanied by comfortable temperature as tourist spot. Since opening in 2015, Kedung Pedut has been visited by tourists. The opening of tourist attractions was certainly accompanying by construction of supporting facilities for tourist access and infrastructure around waterfall location. This is support access to the waterfall point which has quite steep conditions filled with trees and shrubs (Fattah et al., 2017).

The community around Kedung Pedut are Javanese people who are still thick with culture. Initially, the community around Kedung Pedut only used enough forest products to fulfill their daily needs. People live traditionally by utilizing forest products such as cutting down trees to build houses, looking for food and medicine. Utilization of these forest products has been carried out for generations by Javanese people around Kedung Pedut. Javanese tribal people have received a lot of knowledge through generations about various types of plants and how to use them according to their life needs. This study can be studied through an ethnobotany. The study of relationship between humans and plants in their traditional utilization activities (Sukarman \& Riswan, 1992). Meanwhile, the community around Kedung Pedut have also used forest products by making handicrafts such as various kitchen utensils made of bamboo. These handicrafts have higher selling value than the forest products were not processed and immediately sold. This can be studied through bioeconomics.
The opening of Kedung Pedut area as tourist destination has led to changes in vegetation arrangement in this area. Vegetation that was originally there was lost due to logging for build roads and construction of various tourist facilities that support increased tourist visits. The different of vegetation composition caused changes in the use of forest products by community. Changes in the use of forest products by Javanese tribe in Kedung Pedut can be studied with ethnobotany and bioeconomy considering that the Javanese people in Kedung Pedut area have also been touched by technology. This makes the ethnobotany and biobased economy study is important. Therefore, this study was conducted to determine the abundance and utilization of vegetation in Kedung Pedut area by Javanese people in Kulon Progo and potential utilization of various vegetation in the future.

\section{MATERIALS AND METHODS}

\section{Study area}

This research was conducted in area of Kedung Pedut waterfall, Jatimulyo Village, Kulon Progo Regency, Special Region of Yogyakarta on 14 - 15 April 2018 (Figure 1). This location is famous for ecotourism waterfall which has beautiful water color and preserved vegetation in the surrounding area (Figure 2 ).

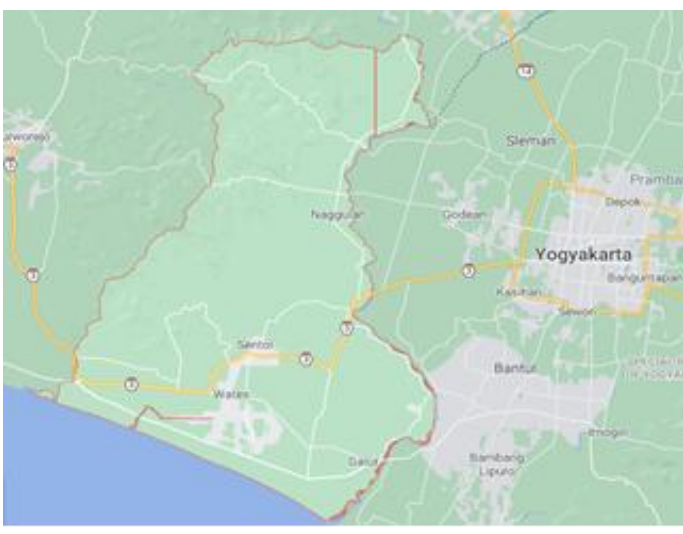

Figure 1. Maps of Kulon Progo Regency 


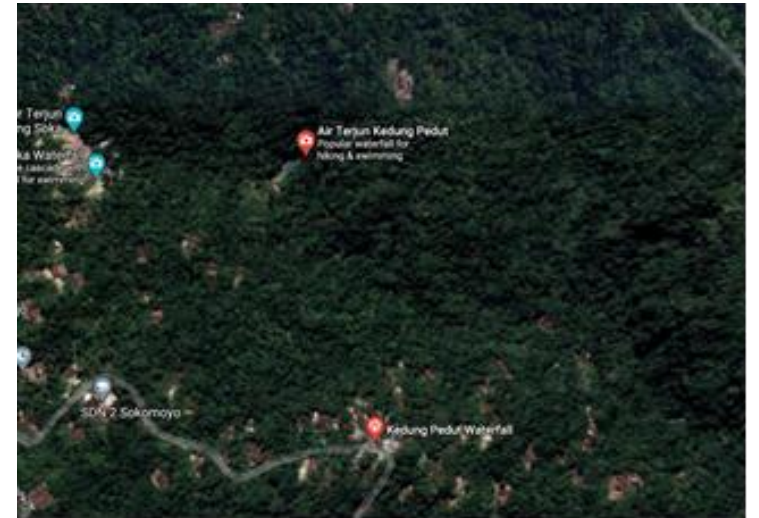

Figure 2. Sampling location at Kedung Pedut Waterfall

\section{Procedures}

Data collection was carried out by using the cat and mouse method (Martin, 1995). Field data were collected simultaneously and then interviews with local community as informants. The first stage, field observations with the roaming method to identify riparian vegetation species. Identification of species was carried out for stand growthform types (with more than $20 \mathrm{~cm}$ of diameter) and in areas along the banks of Kedung Pedut river, including river banks (pankful width) to upland which were affected by water runoff at the highest volume. The next stage is interviews and discussions with the surrounding community as informants. In this case, information related to the use of riparian vegetation species by local community has been explored, then discussed the potential for bioeconomic and future utilization from literature studies.

\section{Data analysis}

The data analysis is quantitative for density of the most abundance vegetation which presented with histogram and descriptive qualitative for vegetation utilization by community. The study is based on ethnobotany and bioeconomic which include identification of riparian vegetation types and utilization techniques to describe more deeply the potential use of riparian vegetation by surrounding community based on technological and scientific developments with the support of scientific literature.

\section{RESULTS and DISCUSSION}

\section{Utilization and Potential of Vegetation}

The results showed that there were 25 species from 15 families of standing vegetation in Kedung Pedut Kulon Progo (Table 1). The largest number of species come from family of Fabaceae. This indicates that this family has an important role in the ecosystem. The selection of the most important plant families is subjective. Nonetheless, two are of unequivocal importance Poaceae and Fabaceae.

Table 1. Vegetation used by the javanese community and potential utilization at Kedung Pedut

\begin{tabular}{|c|c|c|c|c|}
\hline No. & Family & Species & Utilization & Potential \\
\hline 1 & Anacardiaceae & Spondias dulcis & Fruit & Fruit, Leaf, Stem \\
\hline 2 & Anacardiaceae & Mongifera indica & Fruit, Leaf & Stem, Seed, Fruit, Leaf, Root, Flower \\
\hline 3 & Arecaceae & Cocos nucifera & Fruit, Leaf, Stem & Fruit, Leaf, Stem, Root \\
\hline 4 & Arecaceae & Arenga pinuata & Flower, Fruit, Leaf, Stem, Root & Flower, Fruit, Leaf, Stem, Root \\
\hline 5 & Caricaceae & Carica papaya & Fruit, Leaf, Flower & Stem, Seed, Fruit, Leaf, Root, Flower \\
\hline 6 & Combretaceae & Terminalia catcppa & Stem & Stem, Seed, Fruit, Leaf, Root \\
\hline 7 & Fabaceae & Paraseriant hes falcataria & Stem & Stem, Leaf \\
\hline 8 & Fabaceae & Acacia curiculiformis & Stem & Stem, Root \\
\hline 9 & Fabaceae & Dalbergia latifolia & Stem, Leaf & Stem, Leaf \\
\hline 10 & Fabaceae & Leuccena leucocephala & Seed, Leaf & Seed, Leaf, Flower, Stem, Root \\
\hline 11 & Gnetaceae & Gnetion gnemon & Seed, Leaf, Flower & Seed, Leaf, Flower, Stem \\
\hline 12 & Lamiaceae & Tectona grandis & Stem, Leaf & Stem, Leaf, Root, Flower, Seed \\
\hline 13 & Malvaceae & Hibiscus tiliaceus & Leaf, Flower & Fruit, Seed, Leaf, Stem \\
\hline 14 & Malvaceae & Theobroma cacao & Fruit, Seed & Fruit, Seed, Leaf, Stem \\
\hline 15 & Meliaceae & Swietenia mahagoni & Stem, Leaf & Stem, Leaf, Seed \\
\hline 16 & Mraceae & Antocarpus heterophy llus & Fruit, Leaf, Stem, Seed & Fruit, Leaf, Seed, Stem, Flower, Root \\
\hline 17 & Moraceae & Anocarpus altilis & Fruit, Seed & Fruit, Leaf, Seed, Stem, Flower, Root \\
\hline 18 & Misaceae & Misa spp. & Fruit, Leaf, Flower, Root & Fruit, Leaf, Flower, Root, Stem \\
\hline 19 & Myrtaceae & Syzygium aqueum & Stem, Fruit & Stem, Fruit, Leaf \\
\hline 20 & Myrtaceae & Syzygium aromatic um & Flower & Flower, Leaf \\
\hline 21 & Poaceae & Gigantoc hloa apuls & Stem, Leaf & Stem, Leaf \\
\hline 22 & Poaceae & Bambusa blumeana & Stem, Leaf, Shoot & Stem, Leaf, Shoot \\
\hline 23 & Sapindaceae & Scheichera oleosa & Stem, Leaf & Stem, Leaf, Fruit, Seed \\
\hline 24 & Sapindaceae & Nephelium lappaceum & Fruit, Leaf & Fruit, Leaf, Seed, Stem \\
\hline 25 & Sterculiace ae & Guazuma ulmifolia & Stem & Stem, Seed, Fruit, Leaf \\
\hline
\end{tabular}



Fabaceae are herbs, shrubs, trees, lianas or vines usually bearing alternate, pinnately compound, pulvinate, stipulate leaves. $\mathrm{N}$-fixing bacteria are common in two subfamilies: Mimosoideae and Papilionoideae. The androperianth is 5-merous with 10 to numerous stamens (Mimosoideae). The gynoecium consists of a single carpel with 2 to many ovules. Fruits are usually legumes, splitting along two sutures but sometimes indehiscent. The cosmopolitan family contains an estimated 18,000 species in 630 genera. Twenty genera account for nearly half of the species in the family and 16 contain more than 200 species. Fabaceae rank second to Poaceae with respect to human importance. Members of the subfamily Papilionoideae are significant non-animal protein sources. Fabaceae family has great importance as economic source. It is a source of high protein food, vegetable oil, dyes, and forage. Fabaceae are also used as ornamental plants. Many plants of the Fabaceae family provide timber of building, furniture, and fuel. In medicine sector, many plants of this family are used in medicines (Bennett, 2011; Molares \& Ladio, 2012; Rahman \& Parvin, 2014). The community around Kedung Pedut still limited use of vegetation in certain parts so that there are still many potential utilization.

\section{Vegetation Utilization Percentage and Ethnobotany}

The percentage of vegetation parts that most widely used by the community are leaves, stems, fruit, flowers, seeds, roots, and shoots (Figure 3). Leaves are most widely used in relation to people majority who work as farmers. Vegetation are part of biodiversity that always exist in surrounding environment, whether grow wild or cultivated. Traditional communities have long used of the natural resources surround them. Because traditional community life is very close to environment, one of interactions that appears is related to the use of vegetation (Al Liina, Fauziah, \& Nurmiyati, 2017).

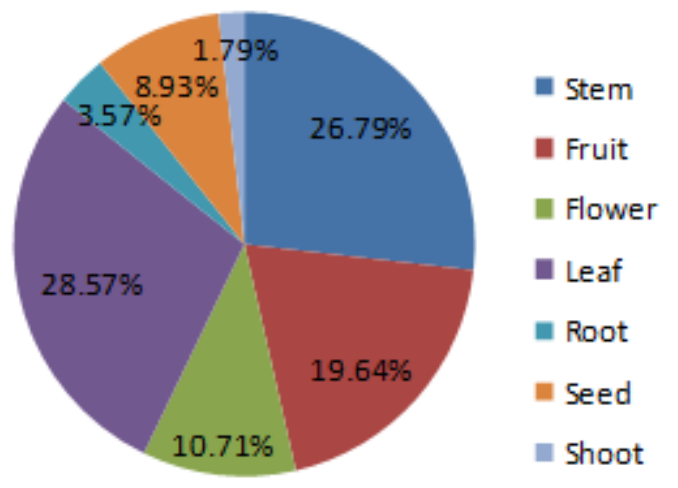

Figure 3. Percentage of vegetation parts utilization

Utilization of vegetation parts by the community around Kedung Pedut aims to fulfill their daily needs. The use of vegetation as food is based on the necessities of daily life. Almost all parts of the vegetation can be used as food. Vegetation as drink characterized by water content in one part of the vegetation. The use of aromatic vegetation is easily seen and observed in the food made by community, either for daily meals or thanksgiving events. Existing aromatic vegetation have 3 functions in people's lives, including air freshener, clothing fragrances, delicious food tastes and aromas (Amboupe, Hartana, \& Purwanto, 2019). For cooking purposes, the whole community uses firewood. This is adjusted to cooking utensils who still use the stove. To get firewood, the community took dry wood branches and dead trees that made it impossible to use as building materials. The main sources of firewood come from gardens and forests. Some parts of community buildings made from vegetation, such as doors, window frames, and roofs. Common vegetation are used to make ropes, plaits and crafts from bamboo, rattan and wood. The use of woven vegetation and handicrafts by community only revolves around the needs of household or kitchen utensils, agricultural tools, and furniture (Hidayat, Hikmat, \& Zuhud, 2010).

The community uses all parts of vegetation from roots to leaves as medicinal substances. Basically the use of medicinal vegetation by the community is simple, only sourced from 
experience and information of previous parents. The medical practice is also not known for the exact dosage, but the most important thing is to process vegetation so that it can be used for treatment (Destryana \& Ismawati, 2020). The treatment performed by the community is categorized into 2 types, treatment for external and internal diseases. External medicine is all treatment related to the outside of human body, such as skin diseases, toothaches, eyes, and wounds. Meanwhile, internal disease is treatment by eating and drinking medicinal plant preparations, such as digestive disorders, high blood pressure, and cleaning the uterus after childbirth. For the purposes of treating external diseases, the parts of vegetation are usually only crushed, grated and rubbed directly onto affected area, such as banana sap for wound medicine. For the treatment of inside body, usually more processing is needed, such as drying in the sun, boiling, brewing or eating directly. Boiled vegetation species are usually used as herbal medicine by the community (Santhyami, 2008).

In agriculture, vegetation are used as fertilizer. Organic fertilizers are produced from plant species. Meanwhile, vegetable pesticides and natural poisons are single or compound active ingredients to control crop pests. Its function can be as repellent, puller, sterile, and killer. Vegetable pesticides are plant-based pesticides that are relatively easy to made with limited skills and knowledge. Vegetation are also used as animal feed. Vegetation as animal feed are all types that given to domestic animals, either directly or mixed. Animal feed is low concentration plant and easy to digest which is edible by herbivores. Livestock feed grows wild in fields, gardens, rice fields and deliberately planted as animal feed reserves during the dry season. Vegetation species as animal feed have quite a variety of habitus compositions. It is not only grass that is used as feed but certain tree levels can be used as animal feed, usually in form of leaves (Hidayat et al., 2010).
Javanese tribal community commonly use leaves as complementary of various traditional and cultural rituals. Vegetation are used in various traditional rituals, such as birth ritual. Javanese tribal generally have a traditional birth ceremony which is divided into several stages including tingkeban/mitoni in the seventh month of womb, and after birth ritual are placenta care, remaining umbilical cord, sepasaran, selapanan, and weton salvation every day birth (35 day cycle) (Al Liina et al., 2017). The wedding ceremony is a ritual that mostly uses vegetation, its existence can be seen in flowers that adorn the walls of bridal house, wedding leaves, and attributes used by the bride and groom. Vegetation are also used in religious rituals on the Prophet's Birthday (Syafitri, Sitawati, \& Setyobudi, 2014). The use of vegetation for aesthetic purposes is observed from vegetation around the community, both inside and outside the home. Identify by observing plants that attract attention and look beautiful. In addition, dye plants are vegetation species that can give color effects to objects, whether food, drink or other objects after being processed beforehand (Kuni, Hardiansyah, \& Idham, 2015)

\section{Species Density and Bioeconomy}

The most abundance of vegetation in Kedung Pedut were Swietenia mahagoni, Paraserianthes falcataria, Cocos nucifera, Bambusa blumeana, and Tectona grandis. The five species with the highest abundance were studied bioeconomically to determine the economic potential of each species (Figure 4).

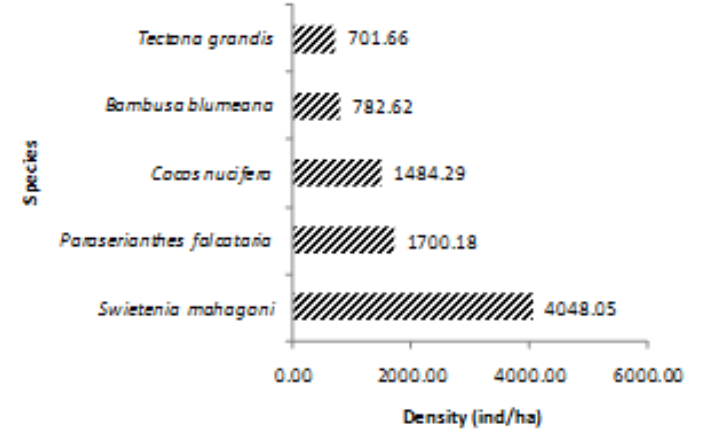

Figure 4. Density of vegetation with highest abundance 
Potential utilization of vegetation in Kedung Pedut area by Javanese people in Kulon Progo based on the development of technology and science are for medicines, agroforestry, food and beverage industry, natural dyes, furniture industry, germplasm conservation, and conservation of environment. S. mahagoni has potential to be used in the parts of stem, seed, and fruit. Stem is used for antiseptic, astringent and febrifuge, decoction for diarrhea and dysentery, vitamins and iron, induce haemorrhage, clear the blood, increase appetite, restore strength in tuberculosis, inhibitory activity on HIV-1 protease, tannins and dyeing. The seeds are used for inhibited platelet aggregation, tetranotriterpenoids, and commercial value of oil. Fruit is used for potting medium (Moghadamtousi, Goh, Chan, Shabab, \& Kadir, 2013; Sahgal et al., 2009). P. falcataria has potential to be used in the parts of stem and leaf. Stem is used for pulp and paper, light construction, furniture, packaging and pallets, wooden shoes, music instruments, veneers, plywood, particleboards, wood-wool boards, blockboards, hardboards, and fuelwood. Leaf is used for fodder of chickens and goats (Iskandar, Iskandar, \& Partasasmita, 2017; Paquit \& Rojo, 2018; Wibowo, 2013).

C. nucifera has bioeconomic value in the parts of seed, fruit, leaf, stem, and root. Seeds is used as very versatile food on raw or cooked, flavoring in cakes, curries, coconut milk or cream, margarines, shortening, filled milk, ice cream, confectioneries, cytotoxic, emetic, emollient, hypotensive and purgative, stiff joints, treat rheumatism and back pains, maintain smooth and soft skin, treat sick new born infants, and peat-free composts. Fruit is used for delicious refreshing drink, diuretic, treat fish poisoning, difficult pregnancies, and treat kidney problems. Leaf is used for vegetable and alcoholic beverage. Stem is used for bread and added to soups or pickled. Root is used for coffee substitute, treating stomach-ache and blood in the urine (Pham, 2016; Siriphanich et al., 2011; Victor, 2013). B. blumeana has potential to be used in the parts of stem, root and shoot. Stem can be used for construction, baskets, furniture, parquets, concrete reinforcements, kitchen utensils, chopsticks, hats and toys, paper, and firewood. Root is used for prevent soil erosion. Shoot is used for vegetables (Abdullah et al., 2019; Setiawati, Mutaqin, Irawan, An'amillah, \& Iskandar, 2017; Sujarwo, 2018; Wróblewska, de Oliveira, Grombone-guaratini, \& Moreno, 2018).

The parts of $T$. grandis that has potential are leaf, stem, root, flower and seed. Leaf is used for natural dye, host of microbe fermentation on tempeh, diuretic, depurative, purgative, stimulant, antidysenteric and vermifuge, treat anemia, asthenia, fever and malaria, amoebiasis, schistosomiasis and tuberculosis, antimicrobe, treat bleeding of larynx, trachea, bronchi, or lungs sore throat, and tender shoots is used against scabies in children. The stem is used for vermifuge, promotes digestion, relieving bilious headaches and tooth aches, reduces inflammation or eruptions of the skin, hair tonic, swelling of the eyelids, astringent and bronchitis. Root is used for eczema, ringworms and inflammation. Flowers are used for diuretics, treat biliousness, bronchitis and urinary disorders. Seed is used for diuretics (Devadiga, Shetty, \& Saidutta, 2015; Vyas, Yadav, \& Khandelwal, 2018).

\section{CONCLUSION}

Tree vegetation with the greatest abundance are Swietenia mahagoni (4048.05 ind/ha), Paraserianthes falcataria (1700.18 ind/ha), Cocos nucifera (1484.29 ind/ha), Bambusa blumeana (782.62 ind/ha), and Tectona grandis (701.66 ind/ha). Potential utilization of vegetation in Kedung Pedut area by Javanese community in Kulon Progo based on the development of technology and science are for medicines, agroforestry, food and beverage industry, natural dyes, furniture industry, germplasm conservation. 


\section{REFERENCES}

Abdullah, W. G., Rianse, U., Ma'ruf, A., Rianse, I. S., Widayati, W., Baka, W. K., \& Indira, R. W. (2019). Potential use of bamboo to support village independence. International Journal of Scientific \& Technology Research, 8(3), 99-105.

Al Liina, A. S., Fauziah, H. A., \& Nurmiyati, N. (2017). Studi etnobotani tumbuhan upacara ritual adat kelahiran di Desa Banmati, Kecamatan Tawangsari, Kabupaten Sukoharjo. BIOSFER, Jurnal Biologi Dan Pendidikan Biologi, 2(2), 2428.

https://doi.org/10.23969/biosfer.v2i2.65 7

Amboupe, D. S., Hartana, A., \& Purwanto, Y. (2019). Kajian etnobotani tumbuhan pangan masyarakat Suku Bentong di Kabupaten Barru Sulawesi SelatanIndonesia. Media Konservasi, 24(3), 278-286.

https://doi.org/10.29244/medkon.24.3.2 78-286

Bennett, B. C. (2011). Twenty-five economically important plant families. Oxford: The EOLSS Publishers Ltd. Retrieved from http://www.eolss.net/SampleChapters/Co9/E6-118-03.pdf

Destryana, R. A., \& Ismawati, I. (2020). Etnobotani dan penggunaan tumbuhan liar sebagai obat tradisional oleh masyarakat Suku Madura (Studi di Kecamatan Lenteng, Guluk-Guluk, dan Bluto). Journal of Food Technology and Agroindustry, 1(2), 1-8. https://doi.org/10.24929/jfta.v1i2.724

Devadiga, A., Shetty, K. V., \& Saidutta, M. B. (2015). Timber industry waste-teak (Tectona grandis Linn.) leaf extract mediated synthesis of antibacterial silver nanoparticles. International Nano Letters, 5(4), 205-214. https://doi.org/10.1007/s40089-015-

0157-4
Fattah, A., Ummah, I. M., Parazulfa, A., Maireda, N. L., Fadhilah, D., Rizky, E. P. S., \& Eprilurrahman, R. (2017). Keanekaragaman dan persebaran Anura di taman wisata air terjun Kembangsoka dan Kedungpedut, Kulon Progo, Daerah Istimewa Yogyakarta. Prosiding Semnas Biodiversitas, 6(3), 28-31.

Hidayat, S., Hikmat, A., \& Zuhud, E. A. M. (2010). Kajian etnobotani masyarakat Kampung Adat Dukuh, Kabupaten Garut, Jawa Barat. Media Konservasi, 15(3), 139-151. https://doi.org/10.29244/medkon.15.3.\% 25p

Iskandar, J., Iskandar, B. S., \& Partasasmita, R. (2017). Introduction of Paraserianthes falcataria in the traditional agroforestry "huma" in Karangwangi Village, Cianjur, West Java, Indonesia. Biodiversitas, 18(1), 295-303. https://doi.org/10.13057/biodiv/d180139

Kuni, B. E., Hardiansyah, G., \& Idham, I. (2015). Etnobotani masyarakat Suku Dayak kerabat di Desa tapang perodah kecamatan sekadau hulu kabupaten sekadau. Jurnal Hutan Lestari, 3(3), 383-400. Retrieved from https://jurnal.untan.ac.id/index.php/jmf kh/article/view/11211

Martin, G. J. (1995). Ethnobotany: A Methods Manual. London: Chapman and Hill.

Moghadamtousi, S. Z., Goh, B. H., Chan, C. K., Shabab, T., \& Kadir, H. A. (2013). Biological activities and phytochemicals of Swietenia macrophylla King. Molecules, 18, 1046510483.

https://doi.org/10.3390/molecules18091 0465

Molares, S., \& Ladio, A. (2012). The usefulness of edible and medicinal Fabaceae in Argentine and Chilean Patagonia: Environmental availability and other sources of supply. Evidence-Based Complementary and Alternative 
Medicine, 2012, 1-12. https://doi.org/10.1155/2012/901918

Paquit, J., \& Rojo, M. J. A. (2018). Assessing suitable sites for falcata (Paraserianthes falcataria Nielsen) plantation in Bukidnon, Philippines using GIS. International Journal of Biosciences, 12(2), 317-325. https://doi.org/10.12692/ijb/12.2.317-325

Pham, L. J. (2016). Coconut (Cocos nucifera). Industrial Oil Crops. Amsterdam: AOCS Press. https://doi.org/10.1016/B978-1893997-98-1.00009-9

Rahman, A. H. M. M., \& Parvin, M. I. A. (2014). Study of medicinal uses on Fabaceae family at Rajshahi, Bangladesh. Research in Plant Sciences, 2(1), 6-8. https://doi.org/10.12691/plant-2-1-2

Sahgal, G., Ramanathan, S., Sasidharan, S., Mordi, M. N., Ismail, S., \& Mansor, S. M. (2009). Phytochemical and antimicrobial activity of Swietenia mahagoni crude methanolic seed extract. Tropical Biomedicine, 26(3), 274-279.

Santhyami, S. E. (2008). Etnobotani tumbuhan obat oleh masyarakat adat Kampung Dukuh Garut, Jawa Barat. Bandung: ITB Press.

Setiawati, T., Mutaqin, A. Z., Irawan, B., An'amillah, A., \& Iskandar, J. (2017). Species diversity and utilization of bamboo to support life's the community of Karangwangi Village, Cidaun Sub-District of Cianjur, Indonesia. Biodiversitas, 18(1), 58-64. https://doi.org/10.13057/biodiv/d180109

Siriphanich, J., Saradhuldhat, P., Romphophak, T., Krisanapook, K., Pathaveerat, S., \& Tongchitpakdee, S. (2011). Coconut (Cocos nucifera L.). Postharvest biology and technology of tropical and subtropical fruits: Cocona to mango (3rd ed., Vol. 32). Woodhead Publishing Limited. https://doi.org/10.1016/B978-1-84569735-8.50002-4
Sujarwo, W. (2018). Bamboo resources, cultural values, and ex-situ conservation in Bali, Indonesia. Reindwartia, 17(1), 67-75.

Sukarman, \& Riswan, S. (1992). Status Pengetahuan Etnobotani di Indonesia. In Prosiding Seminar dan Lokakarya Nasional Etnobotani. Bogor.

Syafitri, F. R., Sitawati, S., \& Setyobudi, L. (2014). Kajian etnobotani masyarakat desa berdasarkan kebutuhan hidup. Jurnal Produksi Tanaman, 2(2), 172-179. Retrieved from http://protan.studentjournal.ub.ac.id/in dex.php/protan/article/view/93

Victor, E. (2013). Cocos nucifera (coconut): A review of its medical properties. Advances in Agriculture, Sciences and Engineering Research, 3(3), 718-723.

Vyas, P., Yadav, D. K., \& Khandelwal, P. (2018). Tectona grandis (teak) - A review on its phytochemical and therapeutic potential. Natural Product Research, 6419, 1-18. https://doi.org/10.1080/14786419.2018.1 440217

Wibowo, S. (2013). Characteristics of bio-oil from sengon (Paraserianthes falcataria L. Nielsen) sawdust by slow pyrolysis process. Jurnal Penelitian Hasil Hutan, 31(4), 258-270.

Wróblewska, K. B., de Oliveira, D. C. S., Grombone-guaratini, M. T., \& Moreno, P. R. H. (2018). Medicinal Properties of Bamboos. In Pharmacognosy - Medicinal Plants (pp. 1-18). London: IntechOpen. https://doi.org/10.5772/intechopen.820 05. 